\title{
Evaluation on the Verification Implementation of Political Parties Participating in the 2019 General Election in Indonesia
}

\author{
Supandi $^{1}$ \\ ${ }^{1}$ Judge at the Indonesian Supreme Court, Indonesia \\ Correspondence: Supandi, Judge at the Indonesian Supreme Court, Indonesia. E-mail: paman_mao@yahoo.com
}

Received: April 20, 2018

doi:10.5539/jpl.v11n2p101
Accepted: May 11, $2018 \quad$ Online Published: May 31, 2018

URL: https://doi.org/10.5539/jpl.v11n2p101

\begin{abstract}
The judgement of the Constitutional Court (MK) Number 53/PUU-XV/2017 oblige all political parties participating in the 2019 general election both established parties or new ones to comply to the re-verification process. Political parties participating in the 2019 General Election must adhere to a verification starting by completing a Political Party Information System (SIPOL). The issue started when the General Election Supervisory Agency (Bawaslu) decided that the SIPOL is not the decisive factor to decide whether a political party passed or failed the administration screening, resulting in the General Election Committee (KPU) to issue a Decision Letter regarding Political Parties participating in the 2019 General Election after the decision of the Bawaslu RI. After the KPU also issued SK Number 58/PL.01.1/Kpt/03/KPU/II/2018 regarding Political Parties participating in the 2019 General Election provoked the political parties stated to fail to become participants in the General Election, to submit complaint through the administrative court. The problem became more entangled when parties winning the complaint in the administrative court reported the KPU commissioners stating to conduct efforts of a judicial review (PK). This paper intents by normative approach to provide an evaluation on the verification process of political parties participating in the 2019 General Election and provide input on the efforts to improve the political parties' verification process in the future.
\end{abstract}

Keywords: verification, political parties, 2019 indonesia general election

\section{Introduction}

A General Election (Pemilu) is a means for Political Party to strive for the aspiration of its members and the community aspiration. Article 22E of paragraph (3) of the Indonesian Constitution of 1945 itself clearly stated "participants in a general election to elect the members of the House of Representatives (DPR) and Regional House of Representatives (DPRD) are political parties".

To be able to become a general election participant, political parties must go through the stages of registration, administrative review and factual verification of the political party participating in the general election conducted by the General Election Committee (KPU) as regulated in Article 173 Law No. 7 of 2017 regarding General Election. Article 173 paragraph (1) Law No. 7 of 2017 regulates that Political Parties Participating in the General Election are political parties which have passed the verification by the KPU. Further paragraph (3) states that Political Parties having passed the requirements of the verification as referred to in paragraph (2) shall not be re-verified and stipulated as political parties participating in the general election.

Article 173 paragraph (1) and paragraph (3) of such $^{1}$ General Election Laws was later tested to the Constitutional Court as it is deemed to be discriminative. The provisions of Article 173 paragraph (1) and paragraph (3) of the General Election Law is regarded to provide a discriminating treatment between political parties which participated in the 2014 general election and political parties which did not yet participate in the 2014 general election. ${ }^{2}$

The Constitutional Court (MK) through its Decision Number 53/PUU-XV/2017 annulled Article 173 paragraph

\footnotetext{
${ }^{1}$ Article 173 paragraph (1) Law No. 7 of 2017 regarding General Election state that Political Parties participating in a general election are political parties pronounced to have passed verification by the KPU. Meanwhile Article 173 paragraph 3 state that Political parties having passed verification under the terms as contemplated in paragraph (2) shall not be re-verified and stipulated as participant political parties in the general election.

${ }^{2}$ Lawsuit filed by several parties namely Party Idaman, PSI, Perindo and also individuals namely Effendi Ghazali
} 
(3) Law No. 7 of 2017 regarding General Election. Such Judgment of the Constitutional Court oblige all political parties participating in the 2019 general election either established political parties and new ones to undergo a re-verification. In its judicial consideration, MK stressed on the justification for all general election participants, territorial expansion and demographical development, political parties as dynamic legal entities, and an overall verification on complying to the requirements for a general election participant as basic of the consideration by all political parties to follow the verification process to be able to be stipulated as general election participants.

Consequences of such MK judgement caused all political parties participating in the 2019 general election both established political parties and new ones to be re-verified without any discrimination and difference in treatment and confirm equal standing in the government participation and state management guaranteed by the constitution.

Further to the implementation of such judgment of the MK, the KPU revised the KPU Regulation Number 11/2017 regarding Registration, Verification and Stipulation of Political Parties Participating in the General Election for Members of the House of Representatives and Regional House of Representatives. This revision caused the KPU to also verify political parties participating in the 2014 general election. ${ }^{2}$

Although in practice there are parties stating that the parties who have participated in the 2014 general election is not verification but only sampling as it needs quite a long time to conduct verification on all political parties participating in the 2014 General Election and quite a big cost while the additional budget submitted by the KPU to the House of Representative was not approved. ${ }^{3}$

Required documents which must be met by Political Parties for the registration as General Election participants itself is regulated in Article 177 of General Election Laws. ${ }^{4}$ KPU required completion at the start of the registration by inputting data through a Political Party Information System (SIPOL). This simplified KPU to assess the preparedness of a political party interested in becoming a participant in the 2019 General Election.

On the other hand, the General Election Supervisory Agency (Bawaslu) through its decision stated that SIPOL is not the decisive factor in passing or not of the administrative screening but only as a supplementary tool. This decision made the KPU to issue a Decision Letter of KPU Number 205/HK/03.1-Kpt/03/KPU/XI/2017 regarding the Process of Registration and Document Examination for Requirements of Candidate Political Parties Participating in the General Election after the decision of the Bawaslu Republic Indonesia which state that the General Election Committee has accepted and physically inspect the registration letter and statement letter along with its attachment and required document by still conducting such document input into the SIPOL until 22 November 2017 at 24.00 WIB.

Although given such opportunity, it turns out that the Political Parties which do not meet administrative requirements are still not able to complete the administrative requirements and therefore an Official Report of the Administrative Screening was issued as a result of the correction to the required documents of political parties candidate participants of the general election at the central level Number 91/PL.01.1-BA/03/KPU/XII/2017 dated 22 December 2017. Such Official Report has become the object of dispute in the State Administrative Court, but the Jakarta State Administrative Court rejected such complaint by the political parties as the dispute object submitted is not the decision of the KPU as regulated in the General Election Law and Regulations of the Supreme Court.

In its development KPU issued a Decision Letter Number 58/PL.01.1/Kpt/03/KPU/II/2018 dated 17 February 2018 regarding Political Parties participants of the 2019 general election of which the content besides mentioning those political parties passing as general election participants also stated the political parties which do not pass as general election participants. It was this matter which caused political parties which have submitted complaint with the dispute object of the State Gazette Number 91 again complaint the Decision Letter

\footnotetext{
${ }^{3}$ Refly Harun in the statement of the Republican court case expert in PTUN Jakarta said the verification should be done to all parties but the fact is only sampling by the KPU because of limited budget and time. This is felt to be unfair to new parties

${ }^{4}$ Article 177 Law No. 7 of 2017 regarding a General a General Election stated: a. The Republic Indonesia State Gazette which stated that such political party is registered as a legal entity; $b$. the decision of the political party central leadership regarding the leadership at the provincial level and leadership at the regency/city level; c. certificate from the political party central leadership regarding the fix office and address of the central level leadership, provincial level leadership and the leadership at the level of the regency/city; d. certificate from the political party central leadership regarding that participation of female at least $30 \%$ (thirty percent) according to the provisions in the law and regulation; e. certificate regarding registration name, emblem, and/or political party emblem from the ministry conducting government business in the field of law and human rights; f. evidence of political party membership of at least 1.000 (one thousand) people or $1 / 1000$ (one per one thousand) from the number of population at each regency/city; g. prove of ownership of account number on behalf of the political party; and h. copy of the articles of association and by laws of the political party according to the stipulation of prevailing laws and regulation.
} 
Number 58/PL.01.1/Kpt/03/KPU/II/2018 dated 17 February 2018 to the Jakarta State Administrative Court. Finally, the Jakarta State Administrative District Court granted granted the claim of PKI and order the KPU to issue a Decision Letter for PKPI as participant of the 2019 General Election.the claim of PKI and order the KPU to issue a Decision Letter for PKPI as participant of the 2019 General Election. ${ }^{5}$

This paper forwards an evaluation and reflection on the verification process of political parties participating in the 2019 general election as an educational material for improvement in the future. This paper applied normative approach based on laws and regulations, regulation and decision letters of KPU which become the object of complaint in the administrative court.

\section{Result and Discussion}

Post the reformation period, the democratic system in Indonesia entered a new era especially with the emergence of a multi-party system in the general election in Indonesia. This is obvious from the presence of 48 political parties in the 1999 General Election, previous to it, in the New Order period, there were only three parties participating in the general election namely Golongan Karya, Partai Persatuan Pembangunan (PPP), and Partai Demokrasi Indonesia (PDI).

This Multi-party system was later offset by the limitation on the number of political parties allowed to take part in the next general election by means of the electoral threshold (ET) mechanism. As Sartori stated the general election system design shall construct the party system. Sartori himself divide the party system into 7 (seven) categories and summaries in 2 big categories; one party, hegemonic party, predominant party, two parties, limited pluralism, extreme pluralism and atomized. These seven parties' system is summarized in 2 big categories: firstly, non-competitive system (one party and hegemonic party). Second, competitive system (include predominant parties, two parties, limited pluralism/moderate, extreme pluralism and atomic. ${ }^{6}$

In 1999 General Election, political parties that do not meet $\%$ seats in the Parliament are not able to participate in the 2004 general election. Therefore, the participants in the 2004 general election dropped from 48 participants in the 1999 General Election to 24 participants in the 2004 General Election. Further to it in the 2009 General Election Article 202 paragraph (1) Law No.10 of 2008 regarding legislative general election was also stipulated a minimum of $2.5 \%$. By this provision, political parties which do not obtained a minimal vote of $2.5 \%$ is not entitled to have representatives in the DPR. The 2014 General Election Participants again underwent a decrease to become only 15 political parties consisting of 12 political parties and 3 (three) local political parties in the Province of Nangroe Aceh Darussalam (NAD).

Approaching the 2019 General Election the challenge for the political parties' candidate for the 2019 General Election is actually not easy. Lawmakers of the General Election Law intended to curtail the number of parties participating in the 2019 General Election through a verification process. Post the judgment of the MK the verification process applies not only to parties which has not participated in the 2014 general election but also to all parties participating in the 2014 general election. This is not easy, especially in meeting documents required and provide evidences in the factual verification.

Such MK judgment is in principle in line with the justice principle or election fairness. According to ACE Electoral Knowledge Network fairness is essential in conducting a general election. There are at least three basic components to conduct a fair general election: sound legal framework, impartial administration and equal treatment. $^{7}$

Related to such quite difficult requirements such matter must be implemented considering that our party system is continuously directed to the limited multi-party system. Besides quite stringent requirements, the short time for political parties which are not yet verified is very hard to obtain the number of members required. As a quite relative new and small political party, such political party needs mean to introduce itself and convey their existence to the public. This of course needs much time and work.

To be able to become a participant in a general election, a political party must go through all the stages in the general election according to Article 173 Law no.7 of 2017 regarding General Election. A party which does not

\footnotetext{
5 In its verdict the judge stated "Annul the decision of the KPU Number 58/PL.01.1-Kpt/03/KPU/II/2018 regarding the stipulation of political parties participating in the 2019 general election which in principle stipulate that PKPI does not meet the requirements as a participant in the general election." and "Order the defendant to rescind the KPU decision letter No. 58/PL.01.1-Kpt/03/KPU/II/2018 regarding the stipulation of political parties participating in the 2019 general election; order the defendant to issue a decision letter concerning the stipulation that plaintiff, PKPI, is a participant in the 2019 general election."

${ }^{6}$ Giovanni, Sartori, 1976, Parties and Party System: A Framework for Analysis. Cambridge University Press.

${ }^{7}$ The ACE Encyclopaedia: Electoral Integrity, 1998
} 
meet the requirements in the administrative process cannot enter the verification stages. The stringent requirements to register as a 2019 General Election participant has caused the number of political parties registering and stated to have completed all the requirements to decline compared to the 2014 general election.

In the previous 2014 general election of 34 political parties were registered as candidate participants for 2014 General Election. 10 political parties passed the verification and became the participants in the 2014 General Election. Meanwhile for the 2019 General Election until the time limit stipulated by the KPU on 16 October 2017 there were 27 (twenty-seven) political parties with legal entities registering as political parties participating in general election detailed 14 (fourteen) political parties where registered and given receipt while 13 (thirteen) did not completed their required documents which must be meet and therefore were not accepted in the registration.

The decrease of political parties registering due to the requirements of KPU at the start of the registration by inputting data through the Political Party Information System or SIPOL ${ }^{8}$. This system is deemed to assist the KPU to observe the preparedness of the political party intending to become participants in the 2019 General Election.

But the fact shows that the intention of formulating General Election Law to simplify the number of political parties in 2019 General Election also proven to be a failure as it turns out that the political parties participating in the national and local general election in Aceh turns out to increase from 15 (fifteen) political parties in 2014 to become 20 (twenty) political parties in 2019.

In the verification process itself the issue which emerged for the political parties which cannot meet the administration requirements and objected to the KPU action which only issued an Official Report and not a Decision Letter, whether they could complaint through the Bawaslu as the General Election Law does not predict stages conducted by the KPU so that there is void which is not included in the dispute of the political parties verification for participants in the general election or the process of the general election dispute. The parties which were not satisfied complaint this matter to Bawaslu and Bawaslu decided that the KPU improve the verification process but due to KPU product is only an Official Report and therefore the complaint submitted is stated not to be acceptable by the Jakarta State Administrative Court.

As described above KPU actually did not issue a Decision Letter regarding political parties which do not pass the administrative details but only an Official Report and later to be issued

a decision of the KPU after all the verification process for political parties participating in the general election are completed. This Decision Letter has become the basic complaint for the political parties who did not accept the KPU decision to the State Administrative Court (PTUN).

This was conducted by PKPI by forwarding this matter to the State Administrative Court after the General Election Committee stated that the PKPI cannot become a participant in the general election as it cannot meet the requirements in existing 73 regencies/cities in four provinces. The KPU decision was also strengthened by the Bawaslu which also refused the claim of the Partai Keadilan dan Persatuan Indonesia (PKPI) as participants in 2019 general election. ${ }^{9}$

Based on Article 664 Law No. 7/2017 it is stated that the Bawaslu has the authority to examine technical procedures for the implementation of the general election stipulated by the KPU.

The Decision of the Bawaslu against PKPI was different with the Bawaslu previous decision which granted the complaint of the Partai Bulan Bintang (PBB) as adjudicated to meet the requirements of the 2019 General Election Participant. Against such decision of the Bawaslu, the KPU must conduct the decision of the Bawaslu. Meanwhile if the KPU and the Bawaslu reject the party's complaints the party can still appeal a complaint to the State Administrative Court. Simply describe the authority regarding the settlement of ethical code violation, administrative violation and the dispute process of the general election can be depicted as shown below:

\footnotetext{
${ }^{8}$ SIPOL itself is a system launched by the KPU to enable the public to peruse the database concerning political parties

${ }^{9}$ Bawaslu stated that PKPI did not meet the requirements as the number of members of its leadership in many regencies and cities were insufficient. Besides PKPI also did not meet the requirements of leadership from 21 regencies/cities requested. The regionals which do not the requirements of membership and national recapitulation PKPI were among others in East java of 15 regencies/cities, in Central java of 26 regencies/cities, West Java of 15 regencies/cities and Papua of 17 regencies/cities.
} 


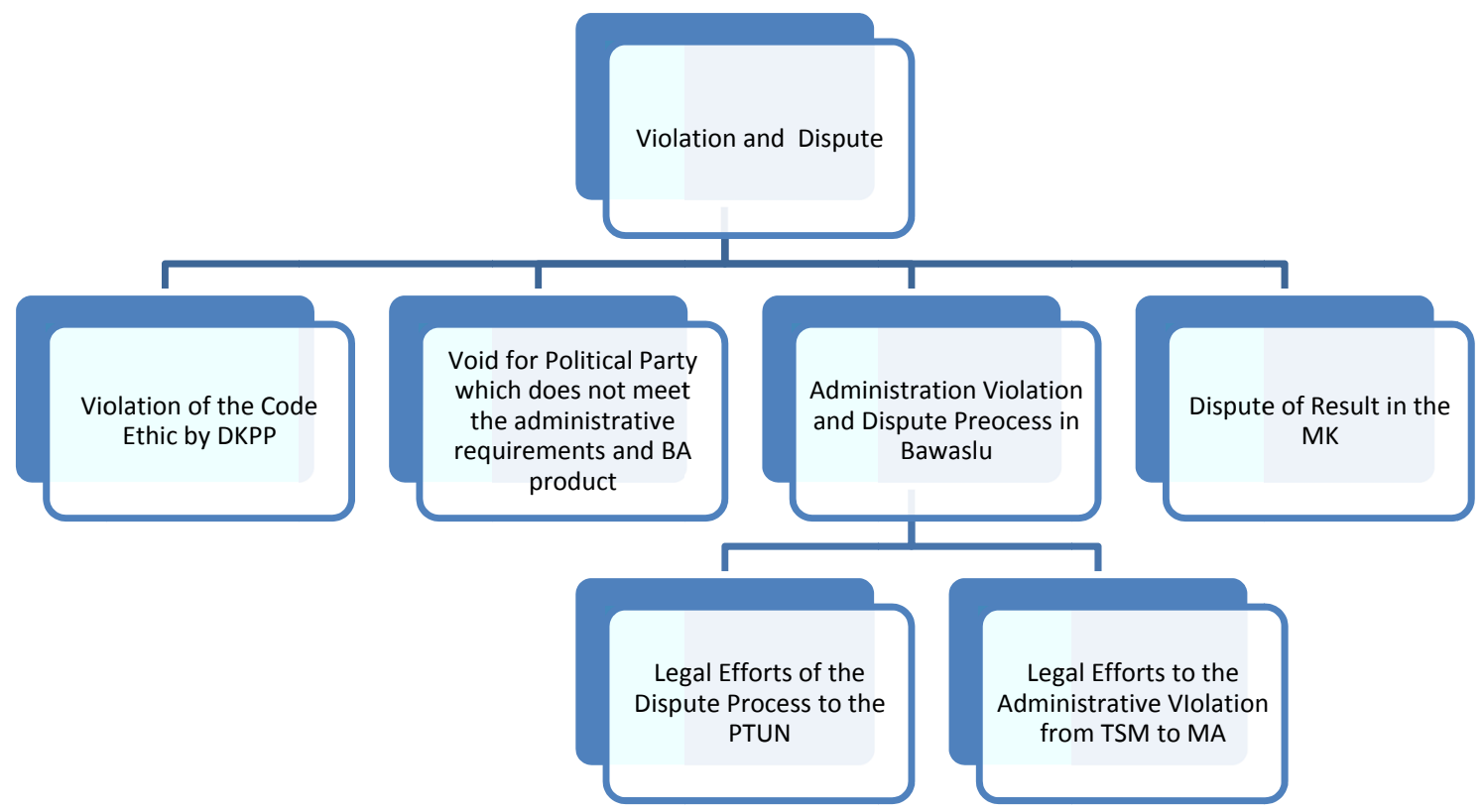

Figure 1. Settlement of violation and dispute of general election ${ }^{10}$

The approach of the PKPI is in line with the regulation of settlement of violation and dispute of a General Election as regulated in the General Election law. Based on Article 470 Paragraph (2) Law Number 7/2017, a General Election dispute process is a dispute arising between the KPU and the Political Party as candidate for the General Election which has not passed the verification because of the issuance of The KPU decision regarding the stipulation of the political parties' participants in the General Election.From the 7 (seven) Political Parties ${ }^{11}$ submitting claims to the Jakarta State Administrative.

The Panel of Judges in the Jakarta State Administrative Court granted all the complaint of PKPI in its judgment the judge refused the exception of the defendant (KPU). In the main law suit, five points was mentioned. Firstly, to grand the complaint of plaintiff overall. Secondly, annul the decision letter of the KPU RI Number 58/PL.01.1-Kpt/03/KPU/II/2018 regarding the Provisions of Political Party Participating in the General Election for Members of the House of Representative, Provincial of House of Representative and Regional House of Representative of the Regency/City in 2019. Thirdly, order the defendant to revoke the decision letter. Fourthly, order the defendant to issue a decision letter regarding the stipulation that plaintiff cq PKPI as a political party participant in the General Election for members of the House of Representative, Provincial House of Representative and Regional House of Representative of the Regency/City in 2019 and Fifthly, to panelized defendant to pay all the cost arising from this law suit amounting to Rp1.186.000.

Further to it related to the judgment of the Central Jakarta State Administrative Court granting PKPI by referring to Article 471 paragraph (7) Law Number 7 of 2017 regarding General Election stated whereas the "Judgment of the State Administrative Court as considered in paragraph (6) is final and binding and no other legal action may be done".

\footnotetext{
${ }^{10}$ Tri Cahya Indra Permana,Wewenang Lembaga Pendaftaran dan Peyelesaian Perselisihan Kepengurusan Partai Politik,Disertasi Universitas Diponegoro ,Semarang,2018

${ }^{11}$ Besides PKPI, Partai Idaman,Partai Bhinneka Indonesia (PBI), Partai Republik, Partai Pengusaha and Pekerja Indonesia (PPPI), Partai Swara Rakyat Indonesia, and Partai Rakyat also submitted a complain to the Administrative District Court. Court actually only the Partai Keadilan dan Persatuan Indonesia (PKPI) which has already conducted factual verification by the KPU while the other parties have not yet conducted it. Finally, only the complain from PKPI was granted by the Jakarta Administrative Court therefore in the end only PKPI was entitled to become a political party participating in the 2019 General Election.
} 
The problem which later arises is that in the General Election Law KPU is also not given the right to conduct any legal action whatsoever on the decision of the Bawaslu and the judgment of the State Administrative Court. Due to it when KPU stated to submit a judicial review (PK) on the State Administrative Court judgment and report the judge adjudicating the law suit of PKPI to KY is clearly obvious that the KPU does not trust the State Administrative Court as an institution given the authority to adjudicate settlement of violation and dispute of a General Election. This has of course become a bad president as there is an attitude of mistrust between authorized institutions.

The passing of the PKPI as political party participant in the 2019 General Election, however, still left an issue when the KPU commissioner Hasyim Asy'ari stated that the KPU still consider the effort to submit a judicial review (PK) with an obtained novum. If the PK is accepted by the judge in the Supreme Court, KPU shall cross out PKPI as a participant in the General Election of 2019. Meanwhile the Chairman of the KPU Arief Budiman also stated to consider reporting the judge of the State Administrative Court to the Judicial Commission regarding such decision.

The PKPI Leadership reported the KPU Commissioner by allegation of defamation through the electronic media according to article 27 paragraph 3 junto article 45 paragraph 3 Law number 19/2016. Amendment of Law Number 11/2008 regarding ITE and or article 310 and or article 311 of the Criminal Law. PKPI object to the statement of Hasyim that if the PK is accepted by the Judge of the Supreme Court (MA), KPU shall cross out PKPI as participant in the General Election of 2019.

The decision of the PKPI leadership to report the KPU commissioner is of course lamentable as it only extends the issue as an impact of the political party verification process which is actually already decided and final. Various issues which took place in the political party's verification approaching the General Election of 2019 can of course be made into evaluation material and valuable lesson for political parties' verification process in the future.

\section{Conclusion}

As an evaluation on the verification implementation of political parties participation in the General Election of 2019, there are several conclusions and also a proposal for the improvement of the verification process of political parties participating in the General Election in the future among others: Firstly, the increase of the political party in the 2019 General Election actually shows a failure in the efforts to reduce the participants in the General Election. This is obvious in the increase of the number of political parties participating in the General Election both national and locally in Aceh from 15 (fifteen) political parties in 2014 to become 20 (twenty) political parties in 2019 .

Secondly, the obligation to conduct factual and administrative verification process conducted by KPU to political parties must be supported by an adequate budget availability so that the factual verification process to political parties participating in a General Election can be objective and transparent. This is important to maintain the standardization requirements required by Law and maintain the implementation of verification stages democratically and justified. In the future, KPU should also issue a decision letter for the respective participants of the General Election pronounce to have passed and not passing separately which its respective considerations. The issue which currently arises is due to the KPU decision containing not only the political parties able to participate in the General Election but also mentioning the parties which has not passed as participant of the General Election.

Thirdly, in the future it is important to review the role of the Bawaslu which was recruited as a supervisor of the General Election but was given the authority to adjudicate. This authority made it to have dual functions as supervisor and as judge.

\section{Acknowledgement}

The writer which to convey thanks to Tri Cahya Indra Permana, Maftuh Effendi, Marta Satria Putra and Teguh Satya Bhakti on their assistant in collecting the writing material and Prof. Dr Yos Johan Utama on his various advices and input to the writing of this paper.

\section{References}

Decision Letter Number 58/PL.01.1/Kpt/03/KPU/II/2018 dated 17 February 2018 regarding Political Parties Participant in the 2019 General Election.

Judgment of the Constitutional Supreme Court Number 53/PUU-XV/2017.

KPU Regulation Number 11/2017 regarding Registration, Verification, and Stipulation of Political Party 
Participant in the General Election for the Members of the House of Representative and Regional House of Representative.

Law Number 10 of 2008 regarding Legislative General Election.

Law Number 7 of 2017 of General Election.

Official Report Administrative Examination because of the improvement to the requirement document of political parties' candidate for the General Election at the central level Number 91/PL.01.1-BA/03/KPU/XII/2017 dated 22 December 2017.

Permana, T. (2018). Cahya Indra, Wewenang Lembaga Pendaftaran dan Peyelesaian Perselisihan Kepengurusan Partai Politik, Disertasi Universitas Diponegoro, Semarang.

Sartori, G. (1976). Parties and Party Systems: A Framework for Analysis. Cambridge University Press.

The 1945 Constitutional Law of the Republic of Indonesia.

The ACE.(1998). Encyclopedia: Electoral Integrity.

The KPU Decision Letter Number 205/HK/03.1-Kpt/03/KPU/XI/2017 regarding Registration and Examination of Required Documents of Candidate Political Parties Post the Decision of Bawaslu RI.

\section{Copyrights}

Copyright for this article is retained by the author(s), with first publication rights granted to the journal.

This is an open-access article distributed under the terms and conditions of the Creative Commons Attribution license (http://creativecommons.org/licenses/by/4.0/). 